\title{
The Re-understanding of Edna Pontellier's Death
}

\author{
Limin Bai \\ College of Foreign Languages, Hebei United University, Tangshan 063009, China
}

\begin{abstract}
Kate Chopin's The Awakening is one of the feminist classics in American literary history. Since its publication in 1899, the novel The Awakening has aroused controversy. Among the heated controversies is the female protagonist's death. The previous discussions on the death of Edna Pontellier are either too reductive or absolute.The primary focus of this thesis is to reexamine Edna's death. Darwinism shook the self-importance of man; nineteenth-century feminist discourse evoked feminine independence and self-identity; Nietzsche denounced the validity of God. On the basis of these, this thesis concludes that Edna's death is neither a punishment nor an escape, but a triumph.
\end{abstract}

\section{Index Terms-Kate Chopin, awakening, death}

Since its publication in 1899, the novel The Awakening has aroused controversy. The changes of the ideological concerns have brought the changes of the nature of these discussions. "In retrospect the early attacks on the book seemed quite simple, a matter of moral condemnation of its main character that was supposed to represent important American values" (Toth, 1990, p338-344). Edna Pontellier's free thoughts and behaviors were not accepted at that period. The attacks on the book were too harsh for Chopin to continue her writing career, and even ended the discussion on the book for almost half a century.

Since 1960s, many critics have begun to reread the book and presented various understandings on it, and Emily Toth was one of earliest Chopin scholars who made a great contribution to the revival of Chopin and her works. With her biography Kate Chopin: A Life of the Author of The Awakening (1990), Emily Toth more than any other American deserves credit for having nourished the Chopin revival. In 1968 there were four articles on Chopin' work; in 1970 there were twenty-five; in 1975 there were forty-one. Chopin' time had, indeed, come. By 1988 four books on her writing had appeared. Cathy N. Davidson, current editor of American literature, notes in her foreword to Kate Chopin Reconsidered that she sees "almost as many submission on Kate Chopin as on any other author. I have done a quantitative analysis, but it certainly seems that we receive essays on Chopin with nearly the same frequency as those on Melville, James, and Faulkner....In less than a generation, she has gone from obscurity to canonization"(qtd in Lynda, 1992, pix). Therefore The Awakening has been ranked into one masterpiece of the literary mainstream.

The study on Kate Chopin' The Awakening may fall into three phases. The first phase was in the year 1899. In this year the novel The Awakening was published, and The Awakening was commented lots of times in almost all the newspapers and in as much magazines as it could. The initial comments were generally negative but commentators still showed that they appreciated Chopin's writing ability, and at the same time they insisted the strong negative attitude toward the novel' moral points.

The second phase was from the 1950s to 1970s. During this period, Chopin's The Awakening was renewed. For example, Edmund Wilson (1962) thought that The Awakening was "beautifully written," but Chopin expressed her anticipation toward D.H. Lawrence in her novel The Awakening (p590). Chopin was finally accepted academically in the 1970s. During this period, the dominant approach to the novel was feminist, which caused the extensive readings on The Awakening, thus creating the focused theme that a strong-minded and independent woman seeking her own identity together with the roles both as wife and as mother. Most understandings derive of what Suzanne Wolkenfeld (1976) calls "the feminist fatalism of presenting Edna as the victim of an oppressive society" (p221). Ringe Donald (1976) more positively, sees her as "a solitary, defiant soul who stands out against the limitations that both nature and society place upon her, and who accepts in the final analysis a defeat that involves no surrender" (p206). Besides, a lot of critics began to emphasize the important position of The Awakening. They argued that The Awakening's importance should be recognized from the phases of both romanticism and realism. Fletcher (1966) cites The Awakening as "an excellent example of the fiction written during the transition from romanticism to realism" (p117-132). Eble (1956) notes that "it anticipates in many respects the modern novel" (p262).

The third phase started from the early $1980 \mathrm{~s}$ and extended into the $21^{\text {st }}$ century. During this period, the dominant approach to the novel is still feminist. The themes of woman's self-identity and free sexuality were a main focus in the exploration of The Awakening. From 1980s to the early 1990s the study on Chopin' work boomed. More papers on Chopin were filed and the central theme of papers on Chopin became increasingly clear in their feminist direction. As critic Margit Stange (1998) asserts, "self-ownership" was central to the project of nineteenth-century feminism (p506). Jennifer (2004) claims that "In life, under the irresistible realm of ideology, Edna could exist only in a female role of limitation. In death, she symbolically enters the realm of nature as she wades into 'the sea', and becomes enfolded in its vast space of innumerable waves. Heroically, Edna escapes oppressive ideology, but tragically, does so only in death" (p72). In The Economics of the Body in Kate Chopin' The Awakening John Carlos Rowe situates Edna Pontellier with "the new economics of speculative capitalism" in Chopin's times, and argues "A woman' rebellion will involve much 
more for Chopin than merely the assertion of her naked self; that rebellion will require a thorough transvaluation of the modes of production that govern both the psyche and the economy of late-nineteenth-century capitalism" (qtd in Lynda, 1992, p121). In the $21^{\text {st }}$ century, the study on Chopin seems to reach a new height. Numerous academic papers are published each year which explore Chopin's works from psychological perspective, aesthetical perspective, philosophical perspective and etc..

The studies on Kate Chopin and The Awakening have a relatively shorter history in China. Since the 1990s, more and more readers have begun to pay attention to Kate Chopin's works, especially her masterpiece The Awakening. A large number of papers on Kate Chopin and The Awakening are also published in the last two decades.

The study on Kate Chopin' The Awakening in China can be divided into two phases. The first phase was from the mid 1980s to 1990s, during which period, Kate Chopin' works were dug out and reread. Several Papers were published, such as Liujuan's "Awakening or Disillusion? - The Awakening of American Women Writer Kate Chopin (1985)", Xie Jianxin's "Chopin and her The Awakening” (1987), and etc.. The earlier studies of this phase focused on the author' life experience and American history and therefore provided plenty of background information about Kate Chopin and the book The Awakening for the later studies. However Kate Chopin and The Awakening didn't receive enough attention at that time.

The second phase started from the mid 1990 s and extended into the $21^{\text {st }}$ century. During this period, the study on Kate Chopin and the book The Awakening developed in both depth and scope. Many critics began to read this book from different perspectives. There are mainly four perspectives. One is feminist, which centers on the heroine to illustrate women's seeking of selfhood and fight for freedom and equality against the patriarchal society. The representative scholars are Jinli and Qin Yaqing, who have published several articles on Kate Chopin, such as "Ameican New Feminine Awakening and Rebellion: Kate Chopin and The Awakening" (1995). More than 15 papers are published in different periodicals. Another perspective is the psychoanalytic, which is on the basis of Freud's theory to elaborate The Awakening and analyze the heroine's psychological development and changes, The example is Miao Lingling's "Freedom Pays_Explaining The Awakening from Freudian Perspective" (2004). The third is Emerson's Transcendentalism, which expounds the elements of transcendentalism in the novel and accordingly illustrates the awakening process from seeking self to realizing spiritual perfection demonstrated by the protagonist Edna, such as Sun Quanjun' The Re-explaining The Awakening from Transcendentalism Perspective (2006). The Fourth is philosophical, which adopts German philosopher Nietzsche's philosophical thoughts such as "Will to Power" and "Superman" to affirm the instinctual impulse of human beings, and illustrates Edna's awakening activities in accordance with Nietzsche's thoughts. One of these studies is Jiang Lifu and Shi Yunlong's "Edna: Typical Embodiment of "Will to Power" - Rereading The Awakening and Explaining Nietzsche's Opinions of Women" (2006).

Most of the studies on Chopin's The Awakening focus on Edna Pontellier' life and women's social situations in the 19th century. Some critics discuss the ending of the book-Edna Pontellier' death, but their discussions on the death of Edna Pontellier are either too simplistic, reductive or absolute. Therefore a thorough and comprehensive study on the Edna Pontellier' death needs to be conducted.

The analysis of Edna's death is of great significance to understand the ending of the novel. In this thesis I try to reinterpret Edna's death from the feminist perspective, and accordingly I will explore the meaning of Edna's death based on naturalism, feminist theory and Nietzschean philosophy. I hope to show that Edna Pontellier' death is neither a punishment nor an escape, but a triumph.

Naturalism is based on social Darwinism. Darwin claims the world is a product of evolution. His theory denies the Judeo-Christian story of the creation of the universe by God in six days, as expressed in Genesis, the first book of the Bible and the semi-divinity of humankind by connecting human beings to the animal world. Edna's "awakening" to the fact of the Darwinian nature of the cosmos alerts her to her freedom from the dictates of God and gods, and also points out the gendered bias of the natural processes of life. To think of the children, and further to submit oneself fully to Darwin's ideologies of survival, is ultimately to give oneself over to a natural process which we have little control and which ultimately controls us. Darwinism offers only an illusory freedom. A world without deities seems to offer the possibility to reshape our lives at will: this is what Edna believes is open to her at first. However, she finally finds that the door into the world is locked and she has no key only because she is a female. The path out of this dilemma is to reassert control in the only way we know how: through taking our own life. Edna insists that she would give her life for her children; but she wouldn't give herself, and she doesn't want anything but her own way. The Darwinian sea, where all life began, is also the Darwinian natural impulses that demand that women should be the re-creators of the species. The sea is the representative of that character and sexuality here. And here the return to the sea maybe finally overwhelms and engulfs Edna, while Edna still bravely swims in the sea finally in the end of the novel as a rebellion for her feminine freedom. Edna's death is as natural as her subordinate position in society, which doesn't mean she was punished to die due to the social morals. Her death is a celebration of Darwinian self.

This is where Edna's Darwinian self comes into its own and she is beginning to realize herself as an individual. She is not one of the herd but an independent person. In a radical rewriting of Darwin, while still an endorsement of his basic principles, Edna's activities are a feminist attempt to renegotiate the survival of the species on a more egalitarian basis. She rejects the role of mother-woman, because in this role she sees the creation of an illusion by Nature herself. The love of a mother for her children is seen by Edna as a dangerous creation by Nature, as Doctor Mandelet points out: 
"The trouble is that youth is given up to illusions. It seems to be a provision of Nature; a decoy to secure mothers for the race. And Nature takes no account of moral consequences, of arbitrary conditions which we create, and which we feel obliged to maintain at any cost" (Chopin, 1993, p111).

Chopin's fiction expresses a complex mixture of influences while her own commentaries suggest that she sees herself as a naturalistic thinker for whom only non-contingent natural forces are of true significance. As a stylist, Chopin despises plot devices and tendentiousness. Scientific theories are her passion and she likes to have her own Darwin, Huxley and Spencer near at all times. These theories of the writing of texts are transformed by the arguments of Charles Darwin in his The Descent of Man and Selection in Relation to Sex (1871). William Schuyler reports that "the subjects which . . . attracted [Chopin] were almost entirely scientific, the departments of Biology and Anthropology having a special interest for her...The works of Darwin, Huxley, and Spencer were her daily companions" (qtd in Seyersted, 1979, p117).

Kate Chopin has been considered a "quasi-anthro-logical" writer with an "almost scientific detachment" (Gilbert, 1983, p16-17), and at times it seems that The Awakening is a parable of post-Darwinian woman. Naturalism provides for a style of writing that allows sexuality to enter the novel without disrupting it. With Darwin, an approach to life which stripped away the layers of religious and mythological significance became intellectually respectable. Darwin's major finding was that humanity was not a special creation at all: "man" was not made in God's image but was biologically lost to the beasts that surrounded him. This naturally allowed naturalist to take full sight - without God a fully secularized literature and a fully naturalized human being seemed not only possible but unavoidable. Darwinism is a crucial influence on Kate Chopin's The Awakening.

The famous sentence of Edna's emerging individuality powerfully conveys this: "In short, Mrs. Pontellier was beginning to realize her position in the universe as a human being, and to recognize her relations as an individual to the world within and about her" (Chopin, 1993, p57).

The path out of this dilemma is to reassert control in the only way she can choose through taking one's own life. Thinking of the children is a reminder that we listen to the genetic calls for reproduction which we are unable to resist except through the process of death itself. Because the burden of Nature falls on one sex to a much greater extent than the other, women necessarily have to bear a heavier burden. Since Edna struggles in a Darwinian world, she can apparently, either accept her destiny to be the vehicle of Nature or reject it through death. Edna insists that she would give her life for her children; but she wouldn't give herself, and she doesn't want anything but her own way.

The Darwinian sea, where all life began, is also the Darwinian natural impulses that demand that women should be the re-creators of the species. The sea is the representative of that character and sexuality here. And here the return to the sea finally overwhelms and engulfs Edna, while Edna still bravely swims in the sea finally in the end of the novel as a rebellion for her feminine freedom. Edna's death is as natural as her subordinate position in society.

"Nineteenth-century feminist discourse was an oppositional ideology, a resistance to obstacles to female fulfillment. The patriarchal ideology of nineteenth-century society required women to be objects in marriage and in motherhood, existing as vessels of maternity and sexuality, with little opportunity for individuality" (Jennifer, 2004, p53). Under the influence of the Darwinism, Kate Chopin makes her heroine realize herself as a human being in the universe, and then with feminist discourse Edna allows her to seek her self-identity in patriarchal society by experimenting with the ideal and alternative roles in turn, which embodied respectively by the female characters in the novel, Adele Ratignolle and Mademoiselle Reisz. Gilman (1966) argues that "each woman has had the same single avenue of expression and attainment," and that "all other doors" are "shut" (p79).Therefore Adele Ratignolle becomes a perfect mother-woman representative shaped by the patriarchal social ideology, while Mademoiselle Reisz, as Peggy Skaggs (1974) states, "an identity built altogether upon selfhood and art is inadequate" (p352), realizes that she refutes the patriarchal ideal female image and accordingly she channels her feminine roles into her music. However, Edna cannot insist her female roles unaccepted by the patriarchal social ideology just because that she realized her self-awakening as a equal individual. Therefore even though "all other doors" are "shut" (Gilman, 1966, p79), neither like Adele Ratignolle who submits to the patriarchal ideology nor like Mademoiselle Reisz who chooses the alternative feminine role to elude the dominant patriarchal ideology, Edna adopts the oppositional role of "free-woman", which threatens violently the patriarchal society. Edna bravely, even with death, faces the conflicts caused by her fight for her self-identity. "She went on and on. She remembered the night she swam far out, and recalled the terror that seized her at the fear of being unable to regain the shore" (Chopin, 1993, p115). Here the shore is the symbol of her original state before her awakening, and she has ever hesitated to keep her original state, while now she totally gives up and she just goes on and on without looking back. So Edna's death is not an escape, but a feminist rebellion.

Louis Althusser (1998) defines ideology as an "imaginary relation to the real relations of existence" (p299). Women obey the requirements of marriage and motherhood, and exist not as the individuals but as attachments of men. Women should subject themselves to men and the patriarchal ideology. Chopin's The Awakening embodies the conditions of sex inequality in the late nineteenth-century, and at the same time try to explore a road for women to seek their selfhood and freedom.

Darwinism shook the self-importance of man, nineteenth-century feminist discourse evoked feminine independence and self-identity, and Nietzsche denounced the validity of God. Apollonian and Dionysian are the two terms from Nietzsche in his book The Birth of Tragedy to designate the two central principles in Greek culture. The paradox of 
Apollonian and Dionysian indicates the two life principles. In contrast to the typically Enlightenment view of ancient Greek culture as noble, simple, elegant and grandiose, Nietzsche characterizes it as a conflict between two distinct tendencies - the Apollonian and Dionysian. The Apollonian in culture he sees as the principle of individuation with its refinement, sobriety and emphasis on superficial appearance, whereby man separates himself from the undifferentiated immediacy of nature. Immersion into that same wholeness characterizes the Dionysian, recognizable by intoxication, non-rationality and inhumanity; this shows the influence of Schopenhauer's view that non-rational forces underlie human creativity. Nietzsche describes how from Socrates onward the Apollonian had dominated Western thought, and raises German Romanticism as a possible re-introduction of the Dionysian to the salvation of European culture. Nietzsche used the names Apollonian and Dionysian for the two forces because Apollo, as the sun-god, represents light, clarity, and form, whereas Dionysus, as the wine-god, represents drunkenness and ecstasy. Nietzsche associated the Apollonian tendency with the instinct for form beauty, moderation and symmetry. The Apollonian corresponds to Schopenhauer's principium individuation. Everything that is part of the unique individuality of man or thing is Apollonian in character; all types of form or structure are Apollonian, since form serves to define or individualize that which is formed; thus sculpture is the most Apollonian of the arts, since it relies entirely on form for its effect. Rational thought is also Apollonian since it is structured and makes distinctions. Dionysus, on the other hand, represents tumult, flux, and disorder. The Dionysian instinct is one of irrationality, violence, and exuberance. The Dionysian, which corresponds roughly to Schopenhauer's conception of Will, is directly opposed to the Apollonian. Drunkenness and madness are Dionysian because they break down a man's individual character; all forms of enthusiasm and ecstasy are Dionysian, for in such states man gives up his individuality and submerges himself in a greater whole: music is the most Dionysian of the arts, since it appeals directly to man's instinctive, chaotic emotions and not to his formally reasoning mind. The paradox of Apollonian and Dionysian indicates the two life principles. In The Awakening, the people around Edna represent either the Apollonian image or the Dionysian image respectively. Typically Robert is the one of the representatives of Apollonian image, while Victor is the one of the representatives of the Dionysian. Ultimately Edna is unable to perfect the Nietzschean ideal--to reconcile the Apollonian and Dionysian in her life. The reason lies in that the Apollonian emphasizes the discreet limitation, illusion and patriarchy while Dionysian emphasizes nature, maternal responsibility. Both of them are inclined to the patriarchal society, and therefore they can not realize the reconciliation on Edna. Simultaneously it indicates that Nietzschean philosophy is masculine. Therefore Edna begins her own journey with a vision as Chopin (1993) describes "A certain light was beginning to dawn dimly within her, - the light which, showing the way, forbids it." (p17). For this vision Sandra Gilbert has described in her "The Second Coming of Aphrodite: Kate Chopin's Fantasy of Desire.” Gilbert (1983) asserts Chopin's projection of "a feminist and matriarchal myth of Aphrodite/Venus as an alternative to the masculinist and patriarchal myth of Jesus"--and her alternative could add a feminist dimension as well as a feminine cast member to the Nietzschean script of Apollonian and Dionysian reconciliation $(\mathrm{p} 44)$. From this perspective Chopin tries to "outdo Nietzsche through a kind of metaphysical transgendering of genders", though the outcomes are a little "ambiguously rendered for certainty" (Bradley, 2005, p57). Therefore we need a standard, which, belonging to the masculine triumph standards, could not more compellingly illustrate the feminist triumph. Again let's turn to Nietzsche to define that standard. Edna, however, "denies not only God but the equally patriarchy reaffirmed by Nietzsche's words. If she is indeed freeing herself from both spiritual and cultural anchor, Edna demonstrates, in the expansiveness of her denial, a plenitude of terror, ambiguity, and seductiveness" (Bradley, 2005, p57-58). Sandra Gilbert (1983) points out that Edna, "neither perfected nor corrupted ... is still swimming when we last see her" (p58). Edna is like some new-born creature, opening her eyes in a familiar world that she has never known, which evidences the Nietzschean concept of eternal recurrence, though the death will follow certainly. While the 19 century' feminine "encounters terror, ambiguity, and seductiveness and stays safely ashore"; Chopin's Edna "leaves the shore and swims to meet them" (Bradley, 2005, p58), thus illustrating that Edna Pontellier' death is neither a moral punishment nor a feminine escape, but a feminist triumph.

While the 19 century' feminine "encounters terror, ambiguity, and seductiveness and stays safely ashore"; Chopin's Edna "leaves the shore and swims to meet them" (Bradley, 2005, p58), thus illustrating that Edna Pontellier' death is neither a moral punishment nor a feminine escape, but a feminist triumph.

\section{REFERENCES}

[1] Althusser. Louis. (1998). "Ideology and Ideological State Apparatuses.” Literary Theory: An Anthology. Malden: Blackwell Press. p299.

[2] Bradley. Patricia L. (2005). "The Birth of Tragedy and The Awakening: Influences and Intertextualities." Southern Literary Journal. Issue 2. p57-58.

[3] Chopin. Kate. (1993).The Awakening. New York: Dover Publication. Inc.. p17- p111.

[4] Eble. Kenneth. 1956."A Forgotten Novel.” Western Humanities Review 10:261-269.

[5] Fletcher. Marie. (1966). "The southern woman in the Fiction of Kate Chopin.” Louisiana History 7. p117-132.

[6] Gilbert. Sandra M. (1983). The Second Coming of Aphrodite: Kate Chopin's Fantasy of Desire. Kenyon Review 5. p16-58.

[7] Gilman. Charlotte Perkins. (1966). Women and Economics. New York: Harper \& Row. Inc.. p79.

[8] Jennifer B. Gray. (2004). “The Escape of the 'Sea': Ideology and The Awakening.” Southern Literary Journal. Issue 1. p 53-72.

[9] Lynda S. Boren; Sara deSaussure Davis. (1992). Kate Chopin Reconsidered: Beyond the Bayou. Baton Rouge: Louisiana State University press. pix. 
[10] Ringe. Donald. (1976). “Romantic Imagery” In The Awakening. ed. Margaret Culley. New York: Norton Critical Edition. P206.

[11] Seyersted. Per. (1979). A Kate Chopin Miscellany. Natchitoches LA: Northwestern State University Press. p117.

[12] Skaggs. Peggy. (1974).“Three Tragic Figures in The Awakening.” Louisiana Studies 13. p 352.

[13] Stange. Margit. (1998). "Personal Property: Exchange Value and the Female Self in The Awakening." Contexts For Criticism. Mountainview: Mayfield Press. p506.

[14] Toth. Emily. (1990). Kate Chopin. New York: William Morrow and Co.. Inc. p338-344

[15] Wilson Edmund. (1962). Patriotic Gore. New York: Oxford University Press. p590.

[16] Wolkenfeld. Suzanne. (1976). "Edna's Suicide: The Problem of the One and the Many." In The Awakening. ed. Margaret Culley. New York: Norton Critical Edition. P221.

Limin Bai was born in Shenyang, China in 1977. She received her master's degree in English Language and Literature from Nankai University, Tianjin in 2007.

She is currently a lecturer in the College of Foreign language, Hebei United University, Tangshan, China. Her research interests include American and British literature, culture, translation and English education. 